\title{
Degradasi Moral Dalam Novel Rembulan Tenggelam di Wajahmu Karya Tere-Liye: Perspektif Sosiologi Sastra
}

\author{
Herman Gusti ${ }^{1 *}$ \\ ${ }^{1}$ Megister Pendidikan Bahasa Indonesia, Universitas Muhammadiyah Malang, \\ Malang, Indonesia \\ *Email: ummherm4n.@gmai.com
}

\begin{abstract}
Dampak negatif dari perkembangan teknologi adalah kemerosotan moral/degradasi moral. Degradasi moral dari pengaruh internet sangat memungkinkan karena pintu akses konten internet tanpa batasan usia membuat dampak negatif bagi anak-anak. Tujuan dalam penelitian ini adalah menganalisis moral tokoh utama yang mengalami degradasi pada novel Rembulan Tenggelam di Wajahmu Karya Tere-Liye. Jenis penelitian merupakan penelitian deskriptif kualitatif menggunakan metode/pendekatan sosiologi sastra. Sumber data penelitian ini adalah novel Rembulan Tenggelam di Wajahmu Karya Tere-Liye. Teknik pengumpulan data yang digunakan yaitu, dengan studi dokumen teknik ini dilakukan dengan cara membaca dan mencacat. Teknik analisis data dilakukan dengan analisis isi (content analyses). Penelitian ini menggunakan metode analisis isi melalui tahap pengumpulan data, penyajian data dan kesimpulan sebagai tahap akhir dalam penelitian. Berdasarkan hasil penelitian, peneliti menyimpulkan bahwa, terdapat 6 bentuk degradasi moral tokoh utama dan 3 bentuk faktor penyebab degradasi moral dalam novel yaitu, faktor lingkungan keluarga (gangguan emosional), keadaan ekonomi (gangguan berfikir), dan sekolah.
\end{abstract}

Kata Kunci: Degradasi Moral, Karya Sastra (Novel)

\begin{abstract}
The negative impact of technological developments is moral decline/moral degradation. Moral degradation from the influence of the internet is very possible because the door to access internet content without age restrictions has a negative impact on children. The purpose of this research is to analyze the moral of the main character who is degraded in the novel Rembulan Tenggelam di Facemu by Tere-Liye. This type of research is qualitative descriptive research using the method/approach of the sociology of literature. The data source of this research is the novel Rembulan Tenggelam di Facemu by Tere-Liye. The data collection technique used is, by studying this technical document, it is done by reading and writing. Data analysis technique is done by content analysis. This study uses the method of content analysis through the stages of data collection, data presentation and conclusions as the final stage in the study. Based on the results of the study, the researcher concluded that, there are 6 forms of moral degradation of the main character and 3 forms of factors that cause moral degradation in the novel, namely, family environmental factors (emotional disorders), economic conditions (thinking disorders), and schools.
\end{abstract}

Keywords: Moral Degradation, Literary Works (Novel)

\section{PENDAHULUAN}

Kemajuan teknologi di era digital tidak terlepas dari sesuatu yang berhubungan dengan internet (Kharisma \& Arvianto, 2019; Muhammad Fikri, Muhammad Zaki Ananda, 2021). Teknologi komunikasi dan informasi berbasis internet merupakan bagian utama dari revolusi 4.0 (Khairunnisa \& IImi, 2020; Quezada et al., 2020). Penggunaan internet pada generasi milinial sudah menjadi kebutuhan bahkan melekat dalam kehidupan sehari-hari. Internet semakin mudah untuk diakses, melalui smartphone sehingga berbagai konten dan informasi diperoleh tanpa mengenal jarak, waktu dan usia (APJI, 2018; Pakpahan \& Fitriani, 2020). Smartphone menjadi

${ }^{*}$ Corresponding author.

Received February 20, 2021; Accepted March 15, 2021; Available online April 25, 2021

(c) 2020 IVCEJ. All Rights Reserved

Indonesian Values and Character Education Journal (IVCEJ) | 15 
alat komunikasi yang selalu dibawa untuk dapat mengakses google, youtube, facebook, dan segala macam media sosial lainnya yang bisa diakses selama bisa tehubung ke jaringan internet (Astuti et al., 2017). Penggunaan smartphone oleh siswa sekolah dasar memberikan dampak positif, namun terdapat sisi negative. Namun kenyataannya, dampak negatif dari perkembangan teknologi adalah kemerosotan moral/degradasi moral. Degradasi moral dari pengaruh internet sangat memungkinkan karena pintu akses konten internet tanpa batasan usia membuat dampak negatif bagi anak-anak (Febrianti \& Yanti, R., \& Noverita, 2020; Sakman \& Bakhtiar, 2019). Degradasi moral sering terjadi di lingkungan sekolah dasar. Guru sekolah dasar sering menjumpai siswa yang berbohong, sikap tidak sopan santun terhadap guru dan kakak kelas dalam berbicara, dan eksistensi berlebihan di media sosial selayaknya orang dewasa.

Dalam menyelesaikan permasalahan degradasi moral tersebut pendidikan karakter merupakan salah satu solusi dari peran pendidik dilingkungan sekolah (Alia et al., 2020; Nasution \& Jazuli, 2020). Pendidikan terkait pandangan terhadap kehidupan dalam lingkungan sosial tidak terlepas dari karya sastra (Marufah et al., 2020). Pandangan tersebut terjadi karena pengarang tidak dapat lepas dari ikatan-ikatan sosial tertentu dalam masyarakat social (Alia et al., 2020). Sastra yang baik tidak hanya merekam kenyataan yang ada dalam masyarakat. Sastra dapat dipandang sebagai suatu gejala sosial (Bagus, 2017; Juanda, 2019). Karya sastra tidak hanya dinilai sebagai karya seni yang memiliki budi, imajinasi, dan emosi, tetapi telah dianggap suatu karya kreatif yang dimanfaatkan sebagai konsumsi intelektual. Salah satu karya fiksi yang dikenal masyarakat adalah novel. Novel merupakan salah satu bentuk prosa fiksi yang tidak terlalu panjang, namun tidak terlalu pendek. Degradasi moral dapat diartikan bahwa moral seseorang terus menerus mengalami penurunan kualitas atau degradasi dan tampak semakin tidak terkendali (Febrianti \& Yanti, R., \& Noverita, 2020; Sakman \& Bakhtiar, 2019). Penurunan kualitas moral seseorang dapat dilihat dari cara tutur kata hingga perilaku orang tersebut akan suatu hal (Nasution \& Jazuli, 2020; Sari, 2019). Novel dengan judul Rembulan Tenggelam di Wajahmu sebagai bahan analisis. Novel Rembulan Tenggelam Di Wajahmu karya Tere Liye di terbitkan pada bulan Januari tahun 2009, yang di terbitkan oleh penerbit Republika, Jakarta. Novel ini menceritakan tentang seorang anak yatim piatu yang bernama Rehan Raujana alias Rey yang tinggal dipanti asuhan dikarenakan orang tuannya meninggal karena kecelakaan. Oleh sebab itu, Rehan menjadi anak bandel karena lingkungan panti asuhan yang buruk. Rehan keluar dari panti asuhan dan memutuskan menjadi preman di terminal.

Temuan penlitian terkait degradasi moral telah dilakukan sebelumnya menyatakan masih ada siswa yang tidak memenuhi indikator sopan santun yang baik dalam berperilaku di sekolah (Febrianti \& Yanti, R., \& Noverita, 2020). Terjadinya degradasi moral memberikan dampak terhadap prilaku remaja (Marufah et al., 2020). Degradasi moral sangat perlu diatasi agar tidak memberi dampak bagi generasi milenial (Sakman \& Bakhtiar, 2019) Persamaan dalam penelitian ini adalah,sama-sama meneliti tentang Degradasi moral. Tujuan dari penelitian ini yaitu menganalisis mengenai moral tokoh utama yang mengalami degradasi dan mendeskripsikan faktor lingkungan kelurarga, keadaan ekonomi, dan sekolah yang menyebabkan degradasi moral pada novel Rembulan Tenggelam di Wajahmu Karya Tere-Liye.

\section{METODE}

Jenis penelitian yang digunakan peneliti dalam menganalisis novel Rembulan Tenggelam di Wajahmu Karya Tere-Liye adalah jenis penelitian deskriptif kualitatif dengan menggunakan pendekatan sosiologi sastra yang difokuskan pada sosiologi karya sastra. Sumber data penelitian ini berupa kata, kalimat dan tindakan, dalam novel Rembulan Tenggelam di Wajahmu karya Tere-Liye. Data yang digunakan dalam penelitian ini yaitu dialog antar tokoh, dan perwatakan dan jalan cerita yang terdapat dalam novel. Teknik pengumpulan data merupakan langkah yang paling strategis dalam penelitian, karena tujuan utama dari penelitian ini adalah mendapatkan data. Teknik analisis data yang digunakan adalah teknik analisis isi. Teknik analisis isi digunakan dengan cara memilih data, menyajikan data berupa kutipan dan penarikan kesimpulan.

\section{HASIL DAN PEMBAHASAN}

Hasil

Berdasarkan penelitian ini, hasil yang diperoleh atas pemaknaan degradasi moral dalam novel dan faktor penyebab dalam novel Rembulan Tenggelam di Wajahmu Karya Tere-Liye dapat diuraikan sebagai berikut. Pertama, tokoh utama yang bernama Rehan yang diceritakan dalam 
novel tersebut, Rehan adalah seorang anak yatim yang tinggal di panti asuhan dan memiliki sifat yang penuh dengan kebencian terhadap penjaga panti asuhan. Sehingga, membuatnya selalu melakukan hal-hal yang buruk salah satunya dengan mencuri. Hal ini dibuktikan dalam kutipan berikut; "Rehan masuk kedalam kamar tempat kiriman hadiah lebaran lalu mencuri baju koko, sarung dan kopiah. Pagi-pagi buta Rehan menjual semua barang itu.Rehan menyumpahi penjaga panti yang sok suci itu. Sok baik, sok mulia. Mana pernah bungkusan itu dibagikan ke mereka? sama seperti sumbangan itu hilang entah kemana. Dimakan sendiri olehnya, Dasar maling! Rehan mendesis benci. Penjaga panti itulah yang sesungguhnya bajingan-penipu. Bangsat." (Liye, 2009). Kedua, Rehan pada akhirnya tidak betah tinggal dipanti asuhan dan memutuskan untuk kabur dan pergi meninggalkan panti asuhan tersebut. Dia berfikir bahwa dengan dia kabur dari panti asuhan maka, Rehan bisa hidup di jalanaan dengan tidak adanya aturan oleh siapapun. Dia tinggal di jalanan dan menjadi preman di terminal Kota dengan gaya yang berbeda seperti anak punk. Rehan menjadi anak yang kasar, dan suka mencuri, selalu menyimpan sejuta kebencian. Dia selalu berfikir bahwa hidupnya penuh dengan kesengsaraan, tetapi dalam hati kecilnya ia selalu bersyukur karena ia adalah bayi yang selamat dari masa lalu yang sekarang tumbuh dewasa. Namun ia tetap hidup dijalanan dengan berbagai profesi salah satunya menjadi penjudi. Hal ini dibuktikan dalam kutipan berikut: "Tidak ada gunanya tinggal disini. Dia bisa hidup sendiri di jalanan. Tidak ada uang tinggal mencuri, tidak ada makanan tinggal memaksa. Kehidupan bebas, sebebas yang dapat dibayangkannya. Rehan menyeringai senang memikirkan ide itu. Menguak lebar, baiklah besok pagi-pagi setelah membalas kelakuan penjaga panti diaakan pergi, itu sungguh ide yang bagus. Maka Rehan tersenyum puas. Pelan jatuh tertidur. Mulailah secara otodidak dia mencuri makanan, mulai berani mangkir kerja sengaja merusak barang-barang dan berbagai perangkai buruk bentuk perlawanan darinya." (Liye, 2009)

Ketiga, pada akhirnya Rehan bersedih karena kehilangan sahabat baiknya yang pernah mengajak dia untuk pulang dan kembali kejalan yang benar. Rehan menyesali perbuatannya. Hal itu dibuktikan dalam kutipan berikut: "Maafkan aku Bapak, maafkan Diar yang nakal. Cengkraman itu melemah dan kalimat itu mengantar segalanya, Diar telah pergi. Tangisan itu menghilang, ruangan itu mendadak senyap. Malam beranjak datang. Sabit menghias angkasa awan kelabu seperti sabut kelapa berserakan memenuhi langit. Membuat suasana terlihat senyap, tidak mendung, tapi menimbulkan perasaan sendu. Rehan hanya bisa melontarkan kata maaf" (Liye, 2009). Keempat, Rehan mengalami kecelakaan dan harus dirawat di rumah sakit, dia harus melakukan operasi ginjal di rumah sakit lbu Kota. Setelah sembuh Rehan di tolong oleh seorang suster, mengantarnya ke sebuah rumah, lebih tepatnya rumah singgah. Disanalah hidup Rehan berlanjut menyenangkan. Rehan di sekolahkan oleh seorang lelaki yang beranama bang Ape. Hal ini dapat dibuktikan dalam kutipan berikut; "Ya, malam itu saat bulan sabit bersinar amat elok, di lorong gang pertokoan yang tertutup dari cahaya apa pun, tiga orang tak dikenalinya datang menyergap buas. Mengibaskan tiga pisau tajam berkilat. Dia melawan sekuat tenaga tubuhnya kekar dan berisi, tapi apa daya kekuatan fisik itu? dia sedang mabuk. Mabuk kemenangan, mabuk minuman keras. Pisau belati itu beringas menusuk perut, paha dan seluruh tubuhnya. Tubuhnya terjerembab bermandikan darah diatas tong sampah. Rehan diantar seorang suster dengan wajah keibuan ke sebuah rumah lebih tepatnya rumah singgah. Disanalah hidup Rehan berlanjut enam bulan terakhir. Hari ini, sesuai pembicaraan Bang Ape dua hari lalu, Ray mendaftarkan diri ikut sekolah informal. (Liye, 2009).

Kelima, Rehan kembali memutuskan untuk pergi jauh dari lbu Kota dan memutuskan pulang kembali ke Kota kecilnya, mencoba melanjutkan hidup. Disana Rehan bekerja di gedung kontruksi ia diangkat menjadi mandor. Hal ini dibuktikan dalam kutipan berikut" Tiga bulan berlalu, Rehan mendapatkan promosi pertamanya: mandor junior. Membawahi 24 buruh kasar lainnya. Rehan menjadi pemimpin yang baik, disukai pekerja-pekerja. Rehan tinggal di kontruksi gedung yang mereka bangun" (Liye, 2009). Keenam, pada suatu hari Rehan bertemu seorang gadis cantik, Rehan jatuh cinta kepada gadis itu. Tetapi takdir berkata lain Rehan tidak bertemu lagi dengan gadis itu, hati Rehan terasa sakit. Hari-harinya penuh dengan gunda gulana, namunpada akhirnya takdir mempertemukan mereka kembali, Rehan tak menyangka bisa berjumpa lagi dengan gadis pujaan hatinya. Rehan mengungkapkan perasaannya kepada gadis itu, dan mereka resmi pacaran. Rehan berniat untuk melamar gadis itu menjadi istrinya. Rehan akhirnya menikahi gadis itu. Hidup mereka sangat bahagia. namun sayangnya mereka tidak dikarunia anak, disebabkan kandungan istrinya lemah. Namun Rehan tetap mencintai istrinya. Suatu hari takdir berkata lain, istrinya meninggal dunia. Hari-hari Rehan terasa sepih, dia menyesali segala perbuatan yang dia lakukan sewaktu tinggal dipanti asuhan hingga sekarang segala kebahagiaan telah direnggut. Namun Rehan mengiklaskan semuanya. 
Degradasi moral siswa semakin memprihatinkan dalam interaksi sosial tidak mempunyai nilai rasa moral atau tidak bermoral. Perkembangan berita di media massa menampilkan berita banyaknya penyimpangan-pernyimpangan perilaku oleh pelajar, seperti perkelahian antar pelajar, pemerkosaan, bullying, narkoba, pelecehan seksual, mabuk dan merokok dilingkungan sekolah. Penyimpangan perilaku jika tidak segera diatasi akan menjadi persepsi seolah-olah menjadi hal yang biasa. Degradasi moral akibat menonton tayangan dewasa membuat anak seusia sekolah dasar sudah mengalami penurunan akhlak dan moral.

Faktor penyebab degradasi moral dalam novel Rembulan Tenggelam di Wajahmu Karya Tere-Liye dapat dibedakan menjadi beberapa faktor diantaranya pertama, faktor lingkungan keluarga. Keluarga merupakan satuan sosial yang paling sederhana dalam kehidupan manusia. Orang tua merupakan pendidik utama dan pertama bagi anak-anak mereka (Alia et al., 2020; Ramdan \& Fauziah, 2019). Nilai sosial sangat berpengaruh terhadap proses kesadaran gender. Nilai sosial berkaitan dengan hubungan pribadi dengan lingkungan sosialnya. Tidak selamanya manusia hanya memikirkan kehidupan pribadinya yang akan membawanya pada keegoisan dan tidak peka terhadap lingkungan sekitar (Prasetiawati, 2018; Sakman \& Bakhtiar, 2019). Kedua, faktor lingkungan sekolah, sekolah merupakan lembaga pendidikan formal yang secara sistematis melaksanakan bimbingan, pengajaran dan latihan dalam rangka membantu siswa agar mampu mengembangkan potensinya. Kutipan "Rehan mendaftarkan diri ikut sekolah informal. "Setidaknya kau punya aktivitas, Ray. Mengisi waktu luang dengan hal-hal positif. Siapa tahu kau akan lebih banyak tersenyum setelah pergi sekolah. Ketiga, faktor Ekonomi merupakan faktor internal yang berasal dari dalam yang dapat mempengaruhi kegiatan atau usaha. Dari pembahasan diatas, sangat penting untuk memberikan pendidikan karakter bagi anak, agar tidak terjadinya degradasi moral, sehingga dapat menciptakan sumber daya manusia yang berkualitas

\section{SIMPULAN DAN SARAN}

Novel Rembulan Tenggelam di Wajahmu karya Tere-Liye ini memiliki degradasi moral dalam tokoh yang mengalami perubahan dari waktu ke waktu. Faktor yang menjadi penyebab terjadinya degradasi moral dalam novel yaitu faktor lingkungan keluarga (gangguan emosional), ekonomi (gangguan berfikir) dan sekolah. Hasil penelitian yang banyak kekurangan dan kelemahan ini dapat memberikan pengetahuan bagi peneliti lain yang membahasmengenai degradasi moral pada novel Rembulan Tenggelam di Wajahmu Karya Tere-Liye. Para pendidik dapat mengambil nilai yang baik, yang terkandung dalam novel Rembulan Tenggelam di Wajahmu karya Tere-Liye.

\section{DAFTAR PUSTAKA}

Alia, S., Resma, N., Nurali, R., Adi, S., \& Hamara. (2020). Budaya Lembaga Pendidikan sebagai Pilar Utama Melawan Degradasi Moral. Khazanah Pendidikan Islam, 2(1), 84-89. https://doi.org/10.15575/kp.v2i2.9283.

APJI. (2018). Infografis Penetrasi \& Perilaku Pengguna Internet Indonesia. Teknopreuner.

Astuti, I. A. D., Sumarni, R. A., \& Saraswati, D. L. (2017). Pengembangan Media Pembelajaran Mobile Learning Berbasis Android. JRPK: Jurnal Riset Pendidikan Kimia, 3(1), 57-62. https://doi.org/10.21009/jrpk.072.10.

Bagus, R. (2017). Kesulitan Menyimak dalam Pembelajaran Bahasa Indonesia (Penelitian Studi Kasus Pada Siswa Kelas 3 Sekolah Dasar Inklusi X Bandung). LITERASI : Jurnal IImiah Pendidikan Bahasa, Sastra Indonesia Dan Daerah, 7(1), 41. https://doi.org/10.23969/literasi.v7i1.277.

Febrianti, F., \& Yanti, R., \& Noverita, A. (2020). Analisis Degradasi Moral Sopan Santun Siswa di SMP Negeri 01 Bandar. Jurnal Ilmiah Mahasiswa, 1(1), 1-10.

Juanda, J. (2019). Pendidikan Karakter Anak Usia Dini melalui Sastra Klasik Fabel Versi Daring. Jurnal Obsesi: Jurnal Pendidikan Anak Usia Dini, 3(1), 39. https://doi.org/10.31004/obsesi.v3i1.126.

Khairunnisa, G. F., \& IImi, Y. I. N. (2020). Media Pembelajaran Matematika Konkret Versus Digital: Systematic Literature Review di Era Revolusi Industri 4.0. Jurnal Tadris Matematika, 3(2). https://doi.org/https://doi.org/10.21274/jtm.2020.3.2.131-140.

Kharisma, G. I., \& Arvianto, F. (2019). Pengembangan aplikasi android berbentuk education games berbasis budaya lokal untuk keterampilan membaca permulaan bagi siswa kelas 1 SD/MI. Premiere Educandum : Jurnal Pendidikan Dasar Dan Pembelajaran, 9(2), 203. https://doi.org/10.25273/pe.v9i2.5234.

Liye, T. (2009). Rembulan Tenggelam di Wajahmu. Republika. 
Marufah, N., Rahmat, H. K., \& Widana, I. D. K. K. (2020). Degradasi Moral sebaagai Dampak Kejahatan Siber pada Generasi Millenial di Indonesia. NUSANTARA: Jurnal IImu Pengetahuan Sosial, 7(1), 191-201. https://doi.org/10.31604/jips.v7i1.2020.191-201.

Muhammad Fikri, Muhammad Zaki Ananda, N. F. (2021). Kendala Dalam Pembelajaran Jarak Jauh di Masa Pandemi Covid-19: Sebuah Kajian Kritis. Jurnal Education and Development Institut Pendidikan Tapanuli Selatan, 9(1), 145-148. https://doi.org/10.37081/ed.v9i1.2290.

Nasution, A. Y., \& Jazuli, M. (2020). Menangkal Degradasi Moral di era Digital bagi kalangan Milenial. Jurnal Pengabdian Dharma Laksana, 3(1), 79-84. https://doi.org/10.32493/j.pdl.v3i1.6304.

Pakpahan, R., \& Fitriani, Y. (2020). Analisa Pemafaatan Teknologi Informasi Dalam Pemeblajaran Jarak Jauh Di Tengah Pandemi Virus Corona Covid-19. JISAMAR (Journal of Information System, Applied, Management, Accounting and Researh), 4(2), 30-36. http://journal.stmikjayakarta.ac.id/index.php/jisamar/article/view/181.

Prasetiawati, P. (2018). Integrated character education model sebagai alternatif solusi mengatasi degradasi moral pelajar Indonesia. Jurnal IImiah Dikdaya, 8(1), 177-186. https://doi.org/10.33087/dikdaya.v8i1.99.

Quezada, R. L., Talbot, C., \& Quezada-Parker, K. B. (2020). From Bricks and Mortar to Remote Teaching: A Teacher Education Program's Response to COVID-19. Journal of Education for Teaching, 46(4), 472-483. https://doi.org/10.1080/02607476.2020.1801330.

Ramdan, A. Y., \& Fauziah, P. Y. (2019). Peran orang tua dan guru dalam mengembangkan nilainilai karakter anak usia sekolah dasar. Jurnal Pendidikan Dasar Dan Pembelajaran, 9(2), 100. https://doi.org/10.25273/pe.v9i2.4501.

Sakman, S., \& Bakhtiar, B. (2019). Pendidikan Kewarganegaraan dan Degradasi Moral di Era Globalisasi. Jurnal Pemikiran, Penelitian IImu-IImu Sosial, Hukum Dan Pengajarannya, 14(1), 1-8. https://doi.org/10.26858/supremasi.v14i1.13301.

Sari, D. N. (2019). Upaya Preventif Guru Kristen dalam Menghadapi Degradasi Moral Anak. Visio Del: Jurnal Teologi Kristen, 1(1), 79-100. https://doi.org/10.35909/visiodei.v1i1.11. 